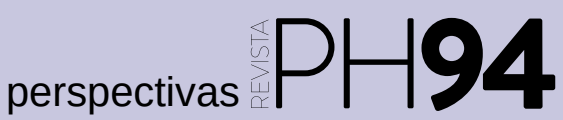

\title{
El patrimonio paleontológico en Andalucía: un gran problema con una sencilla y razonable solución
}

Alfonso Arribas Herrera | Estación paleontológica Valle del río Fardes (Fonelas, Granada), Instituto Geológico y Minero de España

URL de la contribución <www.iaph.es/revistaph/index.php/revistaph/article/view/4182>

En este documento se expone la visión del autor, como paleontólogo con experiencia de campo durante 30 años en yacimientos paleontológicos andaluces, sobre los fósiles y los yacimientos paleontológicos, el patrimonio geológico, el patrimonio paleontológico y el ejercicio profesional del paleontólogo. Para ello, es conveniente, antes de nada, aclarar el problema, presentar una cuestión esencial, recordar algunos conceptos básicos y, finalmente, plantear una solución razonable.

\section{El problema}

La situación actual del patrimonio paleontológico en Andalucía se puede considerar como crítica pues, a pesar de contar con unos registros paleontológicos excepcionales a escala internacional, aquellos con la suficiente relevancia como para ser considerados parte del patrimonio paleontológico se encuentran en un limbo legislativo, reglamentario y administrativo. Esto causa graves problemas (en muchos casos la imposibilidad) tanto para su investigación científica, a ser realizada por profesionales en paleontología, como para su catalogación, protección y puesta en valor.

\section{La cuestión esencial}

Entiendo que todo el problema deriva de la legislación del año 1985. Es razonable asumir que en el planteamiento de los legisladores (tanto en la redacción de la Ley 16/1985 de Patrimonio Histórico Español como en la Ley 14/2007 del Patrimonio Histórico de Andalucía) no ha existido interés o voluntad de prevaricar (según la Real Academia Española de la Lengua, delito consistente en dictar a sabiendas una resolución injusta una autoridad, un juez o un funcionario). Por ello, la lectura de la siguiente frase presente en ambos documentos, referida al patrimonio arqueológico: "Asimismo, forman parte de este Patrimonio los elementos geológicos y paleontológicos relacionados con la historia de la humanidad y sus orígenes y antecedentes" habría de ser literal, sin interpretación posible. Se refiere, entiendo, en exclusividad a los registros arqueológicos de "la historia de la humanidad" con restos culturales y/o tecnológicos generados por cualquiera de las especies perteneciente al género Homo (por tanto, se refiere a los soportes en piedras y rocas -elementos geológicos- o huesos y restos vegetales -elementos paleontológicos- tallados, trabajados o manufacturados por el ser humano).

Pero en la legislación de Cultura y en sus reglamentos se ha ido, por desgracia para este tipo de patrimonio (el paleontológico), más allá.

\section{Conceptos básicos}

Recomiendo, en este punto, la consulta de estas definiciones oficiales en la Real Academia Española de la Lengua: fósil, paleontología, geología y arqueología. Las cosas son lo que son y no debemos cometer por enésima vez el error de re-inventar palabras y términos que ya existen. Esto, en el ámbito de las ciencias, es un grave error.

\section{Desarrollo del planteamiento y consideración}

El patrimonio geológico es parte consustancial del patrimonio natural, y da soporte y cobijo al resto del patrimonio natural de carácter biótico.

Los yacimientos paleontológicos aportan información sobre la evolución de la Tierra y de la Vida. 
a debate El marco legal para la protección del patrimonio paleontológico. ¿Qué pasa en tu comunidad?

Los fósiles y los yacimientos paleontológicos (si tiene un valor altamente significativo) son parte del patrimonio paleontológico, en ningún caso se trata de patrimonio arqueológico, y como tal patrimonio forma parte del patrimonio geológico que es, asimismo, patrimonio natural. Por tanto, no cabe considerarlo como patrimonio histórico o cultural.

Por otra parte, dado que los conceptos son fundamentales y entiendo que no son discutibles, conviene recordar que un fósil es lo que es en cualquier ámbito científico o técnico del planeta, independientemente de la cronología (tenga cientos de millones de años o sólo un millar de años) o de la especie a que represente (tan fósil es una concha de un organismo unicelular o un grano de polen como un cráneo de homínido, o la huella de alimentación de un cangrejo de río). No se pueden segregar competencias en función de cronología o de los taxones, no es serio (no se debe estructurar de forma antropocéntrica la esencia de la naturaleza).

El patrimonio paleontológico, desde la perspectiva legal, queda sujeto a la Ley 42/2007, de 13 de diciembre, del Patrimonio Natural y de la Biodiversidad (Ley estatal): Artículo 3. Definiciones. A efectos de esta Ley, se entenderá por: 38) Patrimonio Geológico: conjunto de recursos naturales geológicos de valor científico, cultural y/o educativo, ya sean formaciones y estructuras geológicas, formas del terreno, minerales, rocas, meteoritos, fósiles, suelos y otras manifestaciones geológicas que permiten conocer, estudiar e interpretar: a) el origen y evolución de la Tierra, b) los procesos que la han modelado, c) los climas y paisajes del pasado y presente y d) el origen y evolución de la vida.

Tal es así, que en las citadas leyes andaluzas previas los conceptos "fósil" o "fósiles" y "evolución de la Tierra" o "evolución de la Vida" no aparecen ni en los "Conceptos" (p. e. Artículo 26 de la Ley 14/2007) ni en todo el desarrollo de esos textos legislativos, quedando pues la gestión de los fósiles y de los yacimientos paleontológicos al margen de estas legislaciones, pero regulados por la Ley 42/2007, de 13 de diciembre, del Patrimonio natu- ral y la Biodiversidad donde legislativamente sí son contemplados.

Consideración: el patrimonio paleontológico debe, y puede, tener un marco legal propio. Y la solución en el caso andaluz es sencilla y razonable. Esta comunidad autónoma lleva varios lustros desarrollando su Estrategia de Gestión integrada de la Geodiversidad, con notable buen hacer y sensibilidad, desde la Consejería de Medio Ambiente. Entiendo que, en este marco y desde esta Consejería, se debería legislar, reglamentar y tutelar el patrimonio paleontológico andaluz con la especificación del justo ejercicio de la profesión de paleontólogo (hasta ahora desarrollada esencialmente por geólogos y biólogos de formación, con alta especialización).

En definitiva, cualquier tipo de patrimonio es de la ciudadanía, las administraciones sólo ostentan su tutela, y por ello se debe aspirar a una reglamentación y una gestión que sean eficientes, justas, razonables y sensibles de los mismos, para el uso y disfrute por parte de la sociedad. Se trata de recursos con un potencial positivo evidente para las sociedades del siglo XXI.

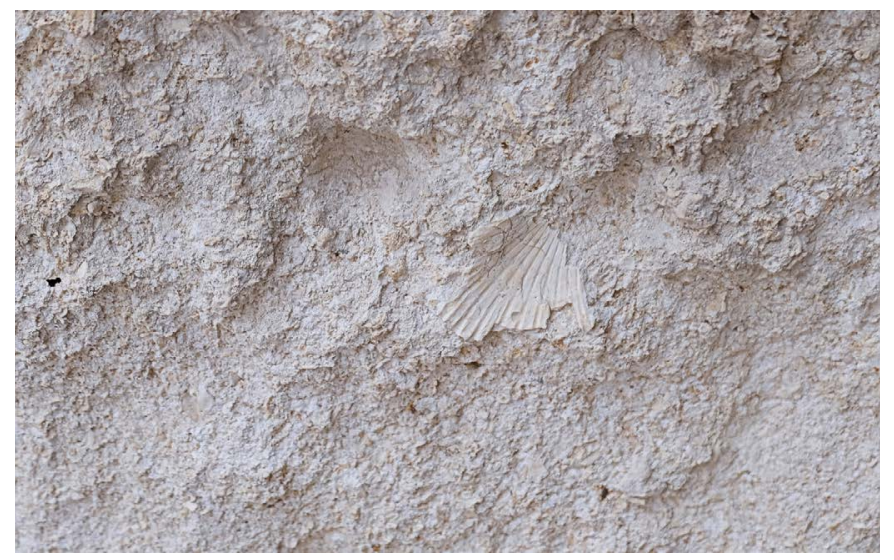

Calcarenitas bioclásticas que forman parte del edificio de la Real Chancillería de Granada, con los fósiles que la integran. Son rocas que provienen de Escúzar, concretamente de la cantera de La Escribana, denominada allí "piedra franca". Este mismo tipo de roca (calcarenita bioclástica), con el mismo lugar de origen, se puede encontrar en la catedral de Granada y el palacio de Carlos V | foto Alfredo Gómez 